\title{
O ensino elementar no Decreto Leôncio de Carvalho: "visão de mundo" herdada pelo tempo republicano?
}

\author{
Marlos Bessa Mendes da Rocha \\ Universidade Federal de Juiz de Fora, Programa de Pós-Graduação em Educação
}

\begin{abstract}
A herança
O recorte de uma história da educação é especialmente favorável a demonstrar continuidades entre Império e República, não tanto pela permanência das ausências, como na interpretação de Fernando de Azevedo, mas pela prevalência dos mesmos fundamentos. Isso ocorre por conta do nosso retardamento em constituir a educação como direito social da cidadania, que é uma marca da modernidade educacional, se nos compararmos não apenas com o que acontecia em um mundo ocidental que nos servia de referência de nação, mas também com o desenrolar dos eventos de política de educação em países vizinhos como Argentina, Chile, Uruguai, que já constituíam a educação como direito, com preocupação abrangente às suas populações, no decorrer da segunda metade doséculo XIX.

Entenda-se por modernidade educacional o surgimento de questões contemporâneas de educação, como, por exemplo, o direito dos povos à educação, a previsão constitucional de aplicação de recursos públicos orçamentários no setor, a incorporação obrigatória
\end{abstract}

à escola do público em idade escolarizável. Embora um desses tópicos tenha aparecido anteriormente - a questão da obrigatoriedade escolar elementar em certa faixa de idade -, somente o conjunto desses quesitos caracterizará essa modernidade, segundo a definição de uma contemporaneidade histórica. Assinalemos, para além da exigência desse conjunto de requisitos, que a obrigatoriedade escolar anterior à modernidade não é ainda um direito à educação no sentido contemporâneo, pois, além de ter outro fundamento social que a justifica, como explicitaremos mais adiante, carece de um requisito fundamental, qual seja a preocupação com a abrangência das populações na faixa de idade determinada em função de se constituir como direito delas. Por suposto, não estamos usando o termo "preocupação" como algo psicológico, pois tratamos de instituições e não partimos de qualquer fundamento epistemológico que crie similitude entre o plano individual e o social; tampouco em dimensão sociológica, pois não se trata de efetivamente alcançar a abrangência, tarefa que de resto a contemporaneidade ainda nos cobra, mas no sentido de um vetor virtual que perpassa políticas públicas de educação 
que se queiram modernas e que pode ser detectado objetivamente.

Por razões que serão demonstradas ao longo do trabalho, a questão do "ensino livre", na forma como foi institucionalmente compreendida no contexto nacional, como livre-oferta de ensino, é a dimensão mais aparente de continuidade entre Império e República, pois prevalecerá até quando vigorou a Lei Rivadávia Corrêa (1911-1915). Não se trata de uma redução de fiscalização pelo Estado sobre o ensino em geral, mas das poucas exigências públicas de quem poderia oferecer o ensino, ocorridas em todos os níveis da educação. O suposto que conduz essa proposição de política pública surge nos últimos 15 anos do Império, passando a predominar institucionalmente com a vigência do Decreto Leôncio de Carvalho, em 1879. ${ }^{1}$ Trata-se da suposição de que o esforço pela ampliação da educação ao povo deve competir à sociedade. Buscava-se corresponder a uma modernidade do mundo, especialmente norte-americano, de "povos dotados de self-government", sem perceber que àquele tempo o movimento institucional dos países que serviam de referência já se fazia no sentido do controle estatal sobre a educação, como Rui Barbosa revelou nos seus Pareceres.

A República, a despeito de seus arroubos modernizadores da educação, da pretensão de criar um novo tempo para a escolarização, de efetivamente construir alguns prédios escolares modelares, de formular, pela palavra de certos ideólogos republicanos, a consciência de que se inaugurava uma nova fase histórica que exigia a incorporação do povo à cidadania, via educação, ainda assim foi herdeira daquele suposto. A nossa hipótese é de que se tratou de uma reificação na República, através do federalismo, de uma "consciência crítica", que se registra institucionalmente, bem como em formulações de autoria, do esgotamento da política

${ }^{1}$ A "livre-frequência" no segundo e terceiro graus, que foi outra importante deliberação do Decreto Leôncio de Carvalho, teve duração mais efêmera, pois já em 1896 é contraditada pelo restabelecimento da frequência obrigatória inicialmente nas faculdades de direito e depois nas de medicina. de centralidade da União, que foi apanágio do Império. Essa "consciência crítica" se exacerba no período que Sérgio Buarque de Holanda (1972) chamou de "crise do Império", a partir de 1870. Quem bem percebeu esse sentido foi Roque Spencer de Barros (1986), ao atribuir o não surgimento de universidade entre nós no século XIX à desconfiança que pesava contra a iniciativa pública. O esgotamento da política de centralidade da União, entendida como geradora de dificuldades para resolver inúmeras questões sociais e políticas, inclusive as de ampliação do ensino, acabou por se confundir com a incapacidade da esfera pública.

Assim, na República continuou a prevalecer o regramento do Ato Adicional de 1834, relegando o ensino elementar inteiramente à esfera estadual. ${ }^{2}$ Mas não foi só nessa dimensão descentralizadora do ensino elementar que a República se tornou herdeira do Império. O nosso argumento buscará ainda a formação, no último quartel do século XIX, de outro suposto, não menos profundo, que continuará em vigor no período republicano. Trata-se da culpabilização do povo pelas dificuldades de implementações de políticas pretendidas. Como diremos mais adiante, foi uma ideia que surgiu ao final do Império, mas não é da tradição do Império. A lei eleitoral n. 842, de 19 de setembro de 1855, a Lei dos Círculos, que modifica a lei de 19 de agosto de 1846, inaugura a preocupação com a "verdade das eleições", nos termos de Joaquim Nabuco (1997, p. 205-208), o que de certa maneira irá pautar as políticas eleitorais do Império, incluindo a de $1881 .{ }^{3}$

\footnotetext{
2 Diga-se que a Reforma Benjamin Constant, de 1890, a
} despeito de se restringir à sede da República, seguindo a tradição dos decretos de ensino do Segundo Império, que se restringiam quase totalmente ao município da corte, pretendeu uma unificação curricular nacional do ensino elementar de $1^{\circ}$ grau, como uma exegese da reforma pode revelar, bem como a colaboração técnica da União com os estados, via Pedagogicum. Porém tal reforma teve vida curta, pois a Constituinte que se avizinhou (1891) acabou com a pretensão unificante.

${ }^{3}$ A reforma eleitoral de 1881, que estabeleceu a eleição direta, a despeito de excluir os analfabetos da participação eleitoral, faz-se ainda sob os argumentos do paradigma estabelecido em 1855, de 
Nossa suposição é de que aí se constituiu uma tradição que procurou alterar as legislações sempre buscando melhor captar a vontade da nação expressa pelos seus eleitores, sem qualquer imputação negativa ao povo que aqui existe.

Ora, o que surge, já nas discussões do Projeto João Alfredo, de 1874, é uma imputação de culpa àqueles a quem se dirige a educação elementar, o povo livre em geral, por negligência ou incúria na frequência escolar. Já não se trata, então, de mudar a legislação para se adaptar ao povo que se tem, mas de culpabilizar este pelas dificuldades de implementações das políticas. A tônica na obrigatoriedade acentua-se, tornando-se estritamente regulamentada, diferentemente da primeira grande matriz da educação na segunda metade do século XIX, que é o Decreto Couto Ferraz, de 1854. O Decreto Leôncio de Carvalho, de 1879, retoma as preocupações do projeto de lei de João Alfredo, acentuando a justificação doutrinária e também ele fazendo um novo e importante deslocamento argumentativo, novamente rompendo com a tradição do Império. Se este justificou, ao longo de suas muitas décadas, a ampliação da educação como exigência de formar eleitores, o último decreto o fará por razões sociais, sejam elas assistenciais ao povo pobre, sejam em decorrência da percepção de ameaças que a pobreza das massas possam trazer às elites.

A nossa narrativa, então, buscou configurar, especialmente a partir do Decreto Leôncio de Carvalho, a formação de uma "visão de mundo", utilizando-se do conceito de Wihelm Dilthey, que adiante qualificaremos. A hipótese é de que essa "visão de mundo" se extrapola ao mundo republicano. Antecipando sinteticamente os nossos argumentos, afirmamos que tal imaginário social das elites governantes do final do

busca da verdade eleitoral. Considera-se que o eleitor alfabetizado e de melhor renda estará menos sujeito às manipulações eleitorais; portanto, mais capaz de expressar a verdadeira vontade do eleitor. É bom observar como esse argumento é completamente distinto daquele usado pela República para manter o critério da exclusão: somente os indivíduos dotados das "luzes" são capazes de participação eleitoral.
Império se caracterizou pela ruptura com uma preocupação que, de certa forma, perpassou os estadistas do antigo regime, qual seja a que estabelecia uma relação entre a sociedade civil e a sociedade política. A desigualdade social profunda naquela sociedade do século XIX não impediu que uma sociedade civil se estabelecesse entre os homens livres a partir da Constituição de 1824, conforme indica bibliografia recente adiante apontada. E a sociedade política, ordenada segundo critérios de renda, não permaneceu impermeável àquela. A ampla legislação educacional do Império, justificando-se ao tempo pelo argumento da exigência de formação do eleitor, é bem indicativa do elo entre as duas sociedades. ${ }^{4}$

Ora, foi justamente essa tradição que se perdeu ao final do Império. A justificativa para a expansão educacional já não se faz para formar o eleitor no velho argumento civilizatório de Bernardo Pereira de Vasconcelos (1999). ${ }^{5}$ Trata-se agora de culpar o público afetado pela educação obrigatória, inverter a ordem do protagonismo social, não mais o Estado, mas a iniciativa privada, e justificar a ampliação educacional pela carência social da população-alvo.

${ }^{4} \mathrm{O}$ elo entre sociedade civil e sociedade política está constituído, na doutrina liberal clássica, desde Locke, ao distinguir três tipos de lei: a divina (pecado e dever), a civil (crime e inocência) e a moral (vício e virtude). A lei moral, embora surja de um foro interior da consciência humana, que Hobbes excluiu da influência sobre o Estado, para Locke, no entanto, não está confinada ao domínio das convicções e opiniões privadas, mas tem caráter de lei social geral. Nesse sentido, cria-se um elo entre o espaço público e o privado. Como disse Koselleck (1999, p. 52), “o espaço privado alarga-se por força própria em espaço público, e é somente no espaço público que as opiniões privadas se manifestam como lei”. Sobre as leis em Locke, ver especialmente Locke (1973, cap. XXVIII).

${ }^{5}$ Diga-se que o argumento eleitoral desse estadista do Império vem relacionado com tudo aquilo que é designado pelas palavras civilização, instrução, educação, cultura etc., e não propriamente fundado numa concepção de individualidade livre e participativa, como elemento essencial da sociedade e do Estado moderno, conforme se configurou doutrinariamente no liberalismo ao final do século XIX. 
A nossa compreensão é de que isso conduziu a uma espécie de imanência sociológica da sociedade vigente entre nós, com atributos sociais e políticos ao povo existente na nação que nos fazia diferentes de outros povos que nos serviam de referência e dos quais saíamos devedores pela carência. Não se tratou de uma redefinição da cidadania, como Koselleck percebeu na Europa ao final do século XIX, que resultou numa certa perda da dimensão política na sociedade civil. ${ }^{6} \mathrm{O}$ que ocorreu entre nós nesse final do Império foi a ruptura entre representação política e legitimidade social. Por mais que o Império nunca se tenha preocupado com legitimação abrangente, como buscamos demonstrar, especialmente a partir do período da pós-maioridade (Gabinete Paraná, 1853), vigorou ali o princípio da ampliação da legitimidade do poder. Por conta disso, as denúncias de interferência do poder pessoal do imperador no jogo político sempre estão marcadas pela preocupação com a perda da legitimidade do poder. O que se tem agora é uma imputação negativa dessa ampliação de legitimidade. Isso não passou despercebido ao tempo, quando da reforma eleitoral de 1881. Ao excluir os analfabetos da participação eleitoral, ainda que sob argumentos ligados à antiga matriz, como dissemos neste trabalho em nota acima, num país de maioria analfabeta, retirou-se o sujeito da oração política, nos termos expressos por José Bonifácio, o moço, deputado pela Província de São Paulo.

Da matriz última de pensamento do antigo regime, a República não escapou. A continuidade deste texto envereda pela tentativa de demonstração de

${ }^{6} \mathrm{O}$ autor refere-se à transformação da natureza da cidadania, ocorrendo uma separação entre Estado e sociedade civil, distanciando-se o conceito de sua formulação original. Nesse novo sentido, a cidadania já não é compreendida como algo que "implica necessariamente uma forma de poder (de exercício de poder). [...] O conceito aplica-se ao entendimento de uma rede de cidadãos (Bürger) que satisfazem livremente suas necessidades [...]. A sociedade civil estaria portanto organizada a partir de condições contratuais entre iguais, sendo as desigualdades presentes em seu seio de natureza econômica, e não política" (Koselleck, 1999, p. 140). nossa narrativa histórica pela reflexão hermenêutica sobre o Decreto Leôncio de Carvalho e pela genealogia histórica que o produziu. No entanto, não temos a pretensão aqui de uma demonstração da herança deixada pelo Império à República no que diz respeito à política de educação, avaliando os procedimentos institucionais e constitucionais do período republicano, o que demandaria espaço bem mais alongado. Restringimo-nos a uma caracterização da natureza da "visão de mundo" que produziu o decreto e a indicação da sua sobrevida.

\section{Leôncio de Carvalho como matriz contraposta e o conceito de "visão de mundo"}

O nosso propósito a partir daqui é entender os significados das proposições do decreto-lei sobre educação de Leôncio de Carvalho, de 1879, no que se refere ao ensino elementar, tanto em termos do contexto político mais geral da época, quanto em termos do que significou na tradição das políticas públicas de educação que se vêm formulando ao longo do Império. Nosso fio condutor serão os termos dos decretos-leis e projetos de lei formulados em todo o período estudado, juntamente com as justificativas apresentadas e debatidas na Assembleia Geral do Império, buscando perceber, numa linha de interpretação hermenêutica, a mudança argumentativa, atribuindo sentidos a partir da compreensão de que mundo provêm as alterações do discurso.

Pode-se dizer que o também Decreto-Lei Couto Ferraz, de 1854, é um ponto de inflexão nas políticas públicas de educação ao longo do Império. Foi ele quem estabeleceu pela primeira vez uma estruturação funcional da educação, que vinha sendo requisitada desde a primeira lei de educação, de 1827. Na compreensão que obtivemos com o estudo do Decreto-Lei Couto Ferraz, chegamos à conclusão de que ele constituiu um paradigma propositivo por parte do Estado na construção educacional, num contexto histórico em que as questões da unidade nacional se encontravam equacionadas. A esse período a nossa historiografia chamou de pós-maioridade. As características dessa 
primeira grande matriz reguladora da política de educação são a de um Estado fortemente proponente da educação, visto ser o caráter ativo muito mais pela regulação e fiscalização do que propriamente pelo investimento público, embora este seja também instigado por ministros e políticos em geral comprometidos no entendimento do papel da educação na formação da sociedade civil. Ali se estabeleceu pela primeira vez uma sistemática de inspetoria do ensino, bem como uma estruturação funcional da educação, via ordenação de suas instâncias. Deu-se o controle sobre o ensino privado, especialmente pelas exigências de exame de capacidade intelectual dos candidatos a mestre. Definiu-se a obrigatoriedade escolar, ainda que de forma frouxa, sem estabelecer sequer a faixa de idade. Outro aspecto fundamental para caracterizar essa fase histórica é a atribuição ao Estado da responsabilidade na construção educacional. A educação é obrigatória, porém o princípio somente se aplicará com o aprimoramento da oferta estritamente pública ou com apoio público. Nesse sentido, a obrigatoriedade não é uma dimensão crucial a ser regulamentada, pois a responsabilização é institucional. ${ }^{7}$ Embora sem a mesma pujança política da Lei de Ensino Comum da Argentina (lei n. 1.420, de 1884), o Decreto Couto Ferraz, de 1854, não deixou de ser a nossa versão de uma política de educação comprometida com a construção de um Estado nacional que então se voltava para a formação da nação (Vasconcelos, 1999). ${ }^{8}$ Esse paradigma sofreu uma erosão ao longo das duas décadas seguintes.

O Decreto Leôncio de Carvalho, por sua vez, caracterizou-se como um verdadeiro novo paradigma da política de educação, num contraponto acentuado com a tradição advinda especialmente do Decreto

${ }^{7}$ O desenvolvimento da nossa reflexão sobre o Decreto Couto Ferraz foi apresentado no V Congresso da SBHE (Aracaju, 2008), intitulado: O decreto Couto Ferraz num contexto de transformação da res publica.

${ }^{8}$ Naturalmente a nossa interpretação contraria compreensões que tomam a construção da nação como um projeto apenas republicano.
Couto Ferraz. O traço marcante da novidade por ele trazida é a controvertida questão do "ensino livre". Sem nos estendermos por agora em todas as dimensões e implicações trazidas por tal consigna, basta que se diga, para dimensionar o contraponto com o decreto anterior, no que diz respeito ao ensino elementar, que ali se abdicou de qualquer controle público, exceto da moralidade, sobre a oferta de ensino que se faça fora do sistema público, estabelecendo sobre tal oferta estímulos de qualidade semelhantes aos produtos de livre-concorrência. Ora, contraria-se justamente aquilo que fora ponto nevrálgico no Couto Ferraz, proveniente de um andamento de discussões públicas sobre educação na Assembleia Geral, que buscou diferenciar essa oferta de serviço de qualquer outro serviço ou produto social. O que se passou na política pública de educação ao longo desse quartel de século que a fizeram enveredar por caminhos tão distintos?

O Decreto Leôncio de Carvalho, senão exaustivamente, é bastante trabalhado pela nossa historiografia. Destacamos dois autores cujos trabalhos, a despeito de formulados há mais de meio século, continuam a nos servir de referência. São eles Almeida Júnior e Roque Spencer de Barros. O primeiro, em três artigos publicados pela Revista Brasileira de Estudos Pedagógicos, no início dos anos 1950, trata da "livre-frequência" no ensino de terceiro grau. ${ }^{9}$ Embora o autor explicite no início de um dos seus artigos o seu suposto historiográfico das ideias fora de lugar, seu trabalho, no entanto, vai muito além desse suposto, bem percebendo de que mundo tais formulações e políticas provinham. O outro autor, Roque Spencer de Barros, em A ilustração brasileira e a ideia de universidade, buscará perceber um sentido de época nos discursos que ali se fazem. Na segunda parte do referido livro, investiga

${ }^{9}$ Os artigos de A. Almeida Júnior são os seguintes: Antes do "ensino livre", RBEP, v. 15, n. 41, jan./mar. 1951; O "ensino livre" de Leôncio de Carvalho (I): o ensino superior brasileiro entre 1879 e 1895, RBEP, v. 17, n. 45, jan./mar. 1952; O "ensino livre" de Leôncio de Carvalho (II): o ensino superior brasileiro entre 1879 e 1895, RBEP, v. 18 , n. 47 , jul./set. 1952. 
as consequências do decreto nos impedimentos que criou à constituição àquele tempo da universidade brasileira. Ambos os autores trazem sugestivas indicações para a pesquisa do decreto, embora não tratem especificamente do recorte que aqui fazemos: o ensino elementar. O que se percebe nessas importantes pesquisas é que o tema ensino superior ali tratado possui um conjunto de eventos de historicidade própria que não são decorrências necessárias do conjunto de ideias e políticas que aqui trataremos. Em termos teóricos, que definiremos a seguir, podemos dizer que aqueles eventos do ensino superior possuem as suas próprias "experiências vitais", das quais decorrem as definições, as formulações e as políticas de "ensino livre" que se estabeleceram nesse nível de ensino.

Em dimensão mais teórica, consideramos que aqueles trabalhos carecem de uma fundamentação no que diz respeito à periodização histórica daquele tempo. Em que o novo tempo se diferencia do tempo pregresso? Se não queremos restringir-nos a um simples fluir de novas ideias no novo tempo, precisamos indagar: $\mathrm{O}$ que mudou no engendrar do novo tempo e por que razões? Isso significa perguntar quais as novas ideias que produzem o novo tempo, bem como o torna receptivo aos ideários vindos de alhures. Nosso suposto é de que novas ideias só são novas se respondem de maneira nova a velhas questões. Trata-se, portanto, neste trabalho, de resgatar a tradição das questões de política de educação relativas ao ensino fundamental advindas de um tempo anterior e indagar de que impasses as novas ideias são devedoras.

O procedimento teórico-metodológico será estabelecer de início o paradigma essencial do Decreto Leôncio de Carvalho, especialmente no nível do ensino elementar, e buscar nas justificativas que o precedem e o acompanham no desenrolar do seu debate na Assembleia Geral a natureza desses argumentos, distinguindo duas ordens de fundamentação: a) a ordem doutrinária; b) a ordem pragmática. As duas naturezas argumentativas decorrem de uma compreensão do que consiste a "visão de mundo", como Dilthey a formula: "Na estrutura da visão de mundo está sempre contida uma relação íntima entre experiência vital e imagem de mundo, uma relação a partir da qual pode ser incessantemente derivado um ideal de vida" (Das Wesen der Philosophie, apud Heidegger, 2008, p. 254). A combinatória dessas duas dimensões, qual seja o peso relativo de um ou de outro argumento numa certa fundamentação, é o que caracteriza a "visão de mundo" que preside tal elaboração. ${ }^{10}$

Mas não nos basta fazer a exegese dos argumentos do decreto e suas justificativas. Entendê-lo é fazer a genealogia da argumentação, buscando em tempos pregressos as diferentes combinatórias que as presidiram. Três outras fases históricas que antecederam em épocas próximas, porém distintas, podem fundamentar uma evolução do argumento. São elas: a concepção de política pública de educação de Liberato Barroso, ministro do Gabinete José Furtado (1864); o projeto de lei de Paulino de Souza, ministro do Gabinete Itaboraí (1870); e o projeto de lei de João Alfredo, ministro do Gabinete Visconde do Rio Branco (1874). A seleção desses três momentos anteriores deve-se à percepção de uma graduação de como os novos

${ }^{10}$ Dilthey (apud Heidegger, 2008, p. 252) antecede a definição de "visão de mundo" com o seguinte argumento: "Em cada momento de nossa existência tem lugar uma relação de nossa própria vida com o mundo que nos envolve como um todo visível. Nós nos sentimos, sentimos o valor vital do momento singular e o valor do efeito das coisas sobre nós. Contudo, isso sempre se dá em relação ao mundo objetivo. Na medida em que a reflexão progride, mantém-se a ligação entre experiência sobre a vida e o desenvolvimento da imagem de mundo". Assim, o conceito referese a um sujeito que contempla o mundo a partir da sua vida interior. Mais adiante no texto fica claro que o que ele está entendendo como "visão de mundo" é uma contemplação que não encerra em si qualquer comportamento prático. Ora, não são esses os sentidos que queremos usar no conceito. Aludimos a ele para pensar dimensões que, embora partam de sujeitos, não são estritamente deles, pois são registros de mundo; embora refira-se a ideias, não são pura especulação subjetiva mas formas de intervenção sobre mundo na forma da construção institucional. É nessa medida que utilizamos as duas dimensões da definição de Dilthey, qual seja, para avaliar uma configuração discursiva e nela buscar perceber de que mundo e de que tempo provêm. 
argumentos foram sendo engendrados, descolando-se progressivamente da matriz de referência primeira, que é o Decreto Couto Ferraz de 1854, até constituir uma nova matriz.

A rigor, a nossa demonstração não quer apenas perceber uma progressividade de descolamento argumentativo da antiga matriz, mas tem a pretensão de fundamentar uma periodização histórica daquele tempo, justamente aquilo que criticamos como ausente na obra de Roque Spencer e na de Almeida Júnior.

Para tratar da tradição das políticas de educação do país independente, que é o nosso recorte histórico, valemo-nos dos relatórios ministeriais e dos projetos legislativos, assim como das amplas justificativas dos projetos de leis encaminhados pelos ministros de Estado à Assembleia Geral. Além dos documentos oficiais, usamos exaustivamente a obra de Primitivo Moacyr. A despeito de alguns historiadores contemporâneos acentuarem o caráter não neutro da obra de Moacyr, valemo-nos de seus relatos como fonte prestimosa para a nossa análise. Em nosso entender, sua obra não peca pelo encobrimento de informações, senão aquele acobertamento que é próprio de qualquer relato histórico em decorrência do seu recorte específico. O discursivo legislativo e o discurso ministerial, como ali contidos, também são para nós fonte primorosa para a análise da lei. Se algum senão sobre esse aspecto pode ser apontado na obra daquele autor, é o seu suposto axiológico de não pretender a interpretação, o que provoca lacunas no seu relato ou aspectos não inteiramente esclarecidos. Nesse sentido, o retorno às fontes originais torna-se necessário. Outra crítica que se faz a Moacyr diz respeito à precariedade dos referenciais dos originais utilizados (Barros, 1986, p. 294). Entretanto, ainda que possamos concordar com a crítica, nada que não possa ser superado com algum trabalho a mais. ${ }^{11}$

${ }^{11}$ Trabalhamos com a obra de Primitivo Moacyr, A instrução e o Império (Subsídios para a história da educação no Brasil, 18541888), São Paulo: Nacional, 1937, v. II.

\section{Pragmatismo e doutrina: a transformação da tradição}

Segundo os termos de Leôncio de Carvalho em sua apresentação à Assembleia Geral, em 1878, do que será a reforma pretendida, são dois os princípios que a norteiam: a liberdade de ensino e a liberdade de consciência (Moacyr, 1937, p. 179). "Que possam ensinar todos aqueles que para isso se julgarem habilitados, sem dependência de provas oficiais de capacidade ou prévia autorização; que a cada professor seja permitido expor livremente suas ideias e ensinar as doutrinas que reputa verdadeiras pelo método que melhor entender" (idem, p. 169). Há aqui a formulação de duas liberdades distintas: 1) a liberdade de ofertar o ensino sem as amarras de qualquer verificação pública do saber de quem oferece o ensino; 2) a liberdade de discernimento do que ensinar. Esse último princípio tem a sua justificativa num liberalismo de ideias que marcou em ampla medida essa fase final do Império, segundo diversos intérpretes. $\mathrm{O}$ argumento justificador do primeiro princípio liberal é a ampla vulgarização e multiplicação dos estabelecimentos de ensino e a própria população exercer a seleção dos mais competentes.

\footnotetext{
$\mathrm{Na}$ classe dos professores serão sempre preferidos os que ensinaram mais e melhor, e a emulação que entre eles desenvolver-se, estabelecida a livre concorrência, reverterá em proveito dos discípulos e por conseguinte da sociedade. O Estado também com ela lucrará, porque terá a mão um pessoal mais habilitado para a escola de professores oficiais; os quais a seu turno, para não verem a sua aula deserta e comprometidos os seus créditos, serão obrigados a estudar mais e a empregar um zelo mais escrupuloso no desempenho da sua missão. (idem, p. 170)
}

Percebe-se que na justificativa há a combinatória de dois fundamentos: a) o de ordem pragmática: a necessidade de expandir a educação pela multiplicação da sua oferta; b) o de caráter doutrinário, pela seleção dos melhores professores pela população que os demanda. O último argumento compreende a educação como um produto de mercado, como outro qualquer, em que 
o público que o utiliza tem condições de escolher o melhor. Se buscarmos as razões históricas de um e de outro fundamento, perceberemos que são distintas. $\mathrm{O}$ axioma doutrinário não é novo na história do Império, pois vigorou durante certo tempo - nas duas primeiras décadas do país independente -, a partir de uma interpretação ampla do artigo $179, \S 24$, da Constituição de 1824, a qual estabelece que "nenhum gênero de trabalho, indústria ou comércio pode ser proibido, uma vez que não se oponham aos costumes públicos, à segurança e saúde dos cidadãos". Ora, mas foi justamente contrário à interpretação extensiva desse artigo à educação que transcorreram os debates na Assembleia Geral do Império sobre as exigências de reforma do ensino e que culminaram no Decreto-Lei Couto Ferraz, de 1854. Vale dizer que esse último decreto estabelece novo paradigma para a educação, bem distinto do que operou naquelas décadas iniciais de formação da nação. Portanto, voltamos nesse final do Império a retomar aquela velha interpretação que vigorou lá atrás. Que razões históricas provocaram o retorno ao "liberismo" inicial no dizer de Sartori (1994)?

Anotamos, a princípio, a percepção do Partido Liberal, que retornou ao poder depois de uma década de afastamento, de esgotamento da política de centralidade administrativa que perpassou o Império, levando-o a buscar suprimir o que compreendia como amarras às iniciativas da sociedade. Não se tratou, no entanto, de uma mudança repentina, a partir daquele retorno dos liberais ao poder. Treze anos após o Decreto Couto Ferraz, já escrevia o conselheiro José Liberato Barroso, ministro da Justiça no Gabinete de Francisco José Furtado, em seu livro A instrução pública no Brasil, publicado em 1867 (2005, p. 61, vocabulário atualizado): "O Estado, cuidando pouco de generalizar e derramar o ensino, cria ao mesmo tempo embaraços à iniciativa individual e à liberdade". Trata-se de uma crítica direta àquele decreto. Não obstante, o argumento aqui não é um contraposto doutrinário, e o seu fundamento de compreensão do papel da educação na sociedade ainda é o mesmo da matriz no decreto de 1854. A demonstração, porém, é longa e terá que ficar para o tópico seguinte.
Mas há ainda o outro fundamento, o pragmático, na justificativa do Decreto Leôncio de Carvalho. É preciso encontrar as suas razões históricas. Também aí se pode encontrar uma raiz de descontentamento com as políticas em vigor. Prevaleceu durante todo o Império, como o demonstra a historiografia contemporânea de educação sobre o século XIX, a preocupação com a expansão da educação à população livre em geral. Uma justificativa possível para essa preocupação estaria no caráter do projeto de nação independente que as elites políticas formularam nos seus primórdios, qual seja de uma nação moderna constituída por uma sociedade civil na qual se forjaria uma representação do seu povo, fundamento, ao lado do corpo do rei, de legitimidade do poder. ${ }^{12}$

Entretanto, os impasses para tal expansão da educação ao povo livre foram permanentes ao longo do Império. Por mais que se saiba que o processo da expansão educacional no mundo ocidental ainda é inicial na segunda metade do século XIX, com algumas exceções em regiões da Alemanha e da Suíça, onde

12 A Constituição de 1824 estabeleceu os direitos civis de todos os cidadãos brasileiros; entretanto, diferenciando-os em seus direitos políticos, de acordo com suas posses. Isso em nada se diferenciava de como a cidadania foi concebida nos EUA e na própria Inglaterra naquele tempo. As discussões em nossa historiografia a respeito da natureza das concepções liberais que vigoravam no país no século XIX, convivendo com a escravidão reinante, sempre acentuaram a absolutização do direito de propriedade como justificativa predominante para a compatibilização entre liberalismo e escravidão (Bosi, 1992; Schwarz, 2000). Tais interpretações, no entanto, se esquecem de acentuar outro aspecto liberal da Constituição de 1824, que é a introdução de uma concepção universalizante de direitos civis do cidadão, suspendendo a "marca de sangue" das antigas Ordenações Filipinas (1603), não totalmente revogadas pelas reformas de Pombal (1776). É precisamente esse último aspecto que irá constituir um vasto campo de contradições e de lutas que marcaram o Império, especialmente na fase histórica do Primeiro Reinado e da Regência, o que demonstra o vigor da definição constitucional de sociedade civil. Ver, a respeito, Mattos (2000). 
o processo se inicia já em final do XVIII, os nossos índices de absorção de crianças e jovens em idade escolar sempre foram muito ínfimos em relação ao mundo que nos servia de referência. A obrigatoriedade da frequência no ensino elementar, tão acentuada em Leôncio de Carvalho, como em projeto de lei anterior, não era capaz de alargar esses números, porque efetivamente a oferta de escolas era pequena em toda parte, inclusive no município da corte. Não faltaram relatórios de "ministros dos Negócios do Império", aos quais estavam vinculados os serviços de educação, dirigidos à Assembleia Geral, destacando a importância do ensino para a nação e procurando transformar os seus projetos de lei em lei, através de votação em plenário, sem no entanto obter sucesso na empreitada. Não é à toa que as duas grandes referências de regulamentação do setor na segunda metade do século XIX, a Couto Ferraz e a Leôncio de Carvalho, se limitam a ser decretos-leis, ou seja, nunca foram votados pela Assembleia Geral, restringindo a sua eficácia apenas naquilo que não implica a verba pública.

Trata-se, a nosso ver, de um limite estrutural da nação que aqui temos, entendido o conceito para além de sua dimensão estritamente econômica ou sociológica. Sem dúvida, havia dimensões geográficas e demográficas que dificultavam as implementações das políticas públicas na nação que se queria construir. Mas, além disso, entretanto, havia também o predomínio de uma representação política parlamentar que efetivamente entravava a realização de políticas de expansão da educação, ainda que formuladas e sinceramente desejadas por estadistas expressivos da elite política imperial tanto do Partido Conservador, como do Liberal. Como justificar tal impasse?

Uma possibilidade de pensá-lo seria, talvez, retomar certas interpretações tradicionais em nossa historiografia, redefinindo-as. O que essas interpretações atribuíram como limite estrutural à expansão educacional, em função dos interesses sociais que predominaram num país escravista e patriarcal, pouco interessado na abrangência educacional da população, pode ser revisitado. Certamente, não mais pensando esses limites de um ponto de vista determinista, como vigorou naquelas interpretações, porém imaginando a limitação como um descolamento entre o projeto de nação idealizado pelos grandes estadistas do Império e as bases de sustentação social e de representação que deveriam apoiá-los. Enfim, a natureza da sociedade impunha o seu preço e exigia que os projetos se redefinissem, fossem eles liberais ou conservadores.

A incapacidade do Estado em aumentar as verbas da educação é, assim, um limite estrutural daquela sociedade patrimonialista. Os limites podem ser percebidos tanto nas dimensões morfológicas daquela sociedade - como as imposições da geografia e da demografia -, como nas configurações dos interesses predominantes cristalizados. A ação social que se pretende inovadora, então, precisa-se defrontar com as restrições que impõem as condições colocadas pela estrutura. A ação social, como efetividade de construção institucional ou reflexão, terá que se fazer dentro das escolhas possíveis. As condições não devem ser entendidas de forma determinista; elas, no entanto, podem ser compreendidas como provenientes dos limites impostos por aquela morfologia da sociedade e pela tradição. E a tradição não se refere apenas aos interesses sociais cristalizados ao longo do tempo, mas também aos projetos político-culturais que configuraram tais interesses. Vale dizer, se os estadistas do Império, sintonizados com a dimensão de res publica do Estado, não eram acompanhados pelos demais representantes da nação, seus liderados, na pretensão de aumento da verba pública à educação, isso não se devia apenas aos marcos classistas da representação política, mas também decorria da própria natureza dos projetos políticos formulados em sua dinâmica responsiva às dificuldades e aos impasses socialmente emergentes.

Tanto o argumento doutrinário como o argumento pragmático nos conduzem à consideração da tradição. É ela que nos dá a referência do mundo possível. Recorrendo aos termos de Dilthey, o sentido do novo impõe-se pelo deslocamento da tradição, trazido por uma nova "imagem de mundo", porém nos limites da "experiência vital", que de alguma maneira decorre dos impasses do antigo projeto diante das novas circunstâncias do mundo. 
A realização de uma genealogia do processo de construção histórica das regulamentações e dos projetos de lei de política pública de educação, reconstruindo a tradição e dando visibilidade aos projetos políticos que a configuram, nos poderá ajudar na inteligibilidade do Decreto Leôncio de Carvalho.

\section{Uma genealogia histórica dos argumentos}

Começamos a nossa genealogia com considerandos sobre a compreensão de instrução pública primária de um livro de época que foi bastante expressivo de um tempo ainda marcado pelas características da primeira grande regulação da instrução pública, na segunda metade do XIX, qual seja o Decreto Couto Ferraz, de 1854. Trata-se do livro do conselheiro José Liberato Barroso, A instrução pública no Brasil, publicado em 1867. ${ }^{13} \mathrm{O}$ autor foi ministro dos Negócios do Império no gabinete liberal de Francisco José Furtado, que assumiu a Presidência do Conselho em 31 de agosto de 1864. É um dos gabinetes do longo período liberal que se iniciou em 1862 e permaneceu até 1868. É uma fase histórica que, de certa forma, dá continuidade à política da conciliação, a do gabinete do Marquês de Paraná (1853-1857), que se seguiu ao período da maioridade (1840-1853), pois como aquela buscou a conciliação de posições conservadoras moderadas com posições liberais. Por isso mesmo, ficou conhecida historicamente como a fase ligueira, de liga, de junção de distintas tradições de política.

Liberato Barroso introduz o seu livro com discursos seus proferidos em sessão da Câmara no ano de 1864. Ali ele expressa um grande desconforto com o que caracteriza como acelerado crescimento do mundo material (estradas de ferro, eletricidade, telégrafo, barco a vapor etc.), gerando rápidas fortunas e provocando a desagregação social. Para o autor, o interesse material é individual e gera desagregação, diferentemente do interesse moral, que agrega. A política pública deve ser conduzida pela moral. É interessante destacar como o argumento moral também

${ }^{13}$ Utilizamos a edição Barroso (2005). aparece na Câmara lá pelos anos da década de 1840, período preparatório do Decreto Couto Ferraz, seja pelo discurso de Francisco de Salles Torres Homem, seja pelo deputado Justiniano José da Rocha. O argumento era de que a proliferação do ensino livre, sem maiores regramentos e fiscalizações das províncias, resultava em perda moral para a população (Moacyr, 1937, p. 263).

Talvez se possa pensar a predominância do argumento moral, no que estamos considerando uma matriz da política de educação nesse largo período histórico, que vai do Decreto Couto Ferraz ao início dos anos da década de 1870 (mais adiante ficará justificado tal extensão do período), como decorrência de uma compreensão comum do que consiste a cidadania nesse tempo. Há inúmeras passagens no livro de Liberato Barroso que indicam a natureza civil-política de como é entendida a cidadania. Ela está ligada à formação do eleitor. E o papel de uma educação estendida ao povo justifica-se precisamente nesse aspecto.

\footnotetext{
Se em todos os países e em todos os governos a educação popular é uma necessidade vital, é muito mais ainda naqueles países que, como o nosso, se regem pelo sistema representativo, naqueles países em que, como o nosso, o povo se governa pelos seus delegados e cujo sistema de governo se baseia sobre a opinião nacional. (Barroso, 2005, p. 20, ortografia atualizada)
}

Como já argumentamos, a formulação da representatividade que perpassa a nação não é mera expressão ideológica de um liberalismo formal que perpassaria as nossas elites intelectuais. Trata-se de um traço relevante do projeto de nação independente que elites dominantes quiseram aqui construir. Somente esse traço poderia explicar o porquê da preocupação com a expansão de escolaridade desde os primórdios do país independente, a começar pela gratuidade do ensino elementar como previsto pela nossa primeira constituição. Dito isso, podemos avançar nos considerandos sobre o pensamento de Liberato Barroso. O governo de caráter representativo requer "cidadãos" bem formados; a razão pública assim o exige, pois 
“o sufrágio popular é geralmente considerado como verdadeira origem da legitimidade dos governos" (idem, p. 46).

Religião, família e escola, eis o trio constitutivo da formação moral da sociedade. A escola não pode substituir a família e a religião na formação moral, mas também a família não pode, por si, garantir a boa escolha do mestre, pois ele não é um produto de mercado. Em contrapartida, uma seita religiosa não pode instalar-se na escola sem prejuízo dos que a ela não pertencem. Então, o ensino deve ser secularizado, embora de forte formação moral; a religião deve estar na escola, mas fora do horário regular. E a família, que é a garantia da ordem social, somente se organiza bem com um bom sistema de educação, porque este está na base da constituição da civilização moderna (idem, p. 40). Assim se entrelaçam as instituições básicas da sociedade para bem enfrentar a dinâmica "material" do mundo moderno que pode ameaçar os valores morais constitutivos da boa ordem social.

O protagonismo do Estado na educação justificase como exigência da "unidade moral da nação" (idem, p. 54). O Estado é esse correlato laico da religião na construção moral do país. É ele que irá construir "uma grande e preciosa unidade [...] entre todos os homens, entre todos os meninos destinados a ser no futuro contemporâneos, compatriotas, concidadãos de uma mesma família, embora devam ocupar posições diversas na mesma nação e na sociedade" (idem, p. 55). Por conta disso, o ensino deverá ser obrigatório, pois não se pode reconhecer o direito de pais de eximir seus filhos de se tornarem cidadãos, pois assim o exige a sociedade e a nação que aqui temos.

Interessante assinalar que o argumento em nenhum momento resvala para o reconhecimento de que a educação é um direito do menino, do futuro cidadão, que nem mesmo o pai poderia retirá-lo. O que justifica a educação obrigatória é a razão pública da sociedade, o que nos parece bem indicativo de um tempo em que a educação ainda não se constituiu como direito do indivíduo, mas como razão de Estado.

A par da obrigatoriedade, prega-se o "ensino livre" como um direito de escolha dos pais de onde e de como devem ser educados seus filhos. O direito, à primeira vista afirmado como princípio de doutrina, é seguido, entretanto, de considerandos práticos, tais como: "liberte-se o ensino particular: assim as dificuldades desaparecerão" (idem, p. 60). Ou como aquela citação a que já fizemos referência, em que o Estado é acusado de negligenciar na generalização do ensino ao mesmo tempo que cria embaraços "à iniciativa particular e à liberdade". Isso nos leva a crer, juntamente com os demais argumentos já tecidos, que se trata de um desgaste do decreto de 1854 diante da incapacidade do Estado em ampliar a sua ação na oferta de ensino público; não obstante, está longe de expressar uma mudança do paradigma que configurou aquele decreto. O coração da matriz do velho Decreto Couto Ferraz está justamente na responsabilização do Estado na questão educacional, como dever moral que se traduz na exigência de constituir uma sociedade civil representativa. Nesse aspecto, os argumentos de Liberato Barroso encontram-se inteiramente ali contidos.

Em 1868 cai o gabinete liberal de Saraiva, interrompendo um longo período de gabinetes liberais vindos desde 1862. O retorno dos conservadores ao poder tem forte impacto, não tanto no paradigma da política pública de educação, mas no campo das disputas partidárias, que acentuaram no Partido Liberal, excluído do poder, as críticas ao centralismo monárquico, às interferências do Imperador no processo político e ao próprio mecanismo de reprodução das situações de poder (o sorites de Tomás Nabuco). Se as disputas no período da pós-maioridade foram mornas por conta da política de conciliação e depois a da liga, que juntou liberais e conservadores moderados, após 1868 se dá uma radicalização dos liberais excluídos. O teor da crítica, que inicialmente se dirigia ao Poder Moderador, por conta das interferências do Imperador no processo político, acaba por resultar, ao longo do tempo, em crítica às intervenções do Estado sobre a sociedade. Como dissemos antes, o fenômeno foi detectado por Roque Spencer de Barros (1986), ao perceber como o ambiente geral de crítica ao poder dificultou a criação de universidade entre nós, pois esta 
teria que contar com a iniciativa estatal. ${ }^{14} \mathrm{Em}$ termos da educação elementar, o resultado não é imediato, porém criará o ambiente político para as mudanças que ocorrerão.

O gabinete conservador de 1868 tem como "ministro dos Negócios do Império" Paulino de Souza, filho do Visconde de Uruguai, e, como o pai, um dos chefes principais do Partido Conservador. O compromisso do ministro, como de resto do seu partido, é com o velho paradigma da extensão da educação à população livre, compreendido por ele como altruísmo das "classes mais elevadas" com o povo livre da nação. No seu relatório à Assembleia Geral, do ano de 1869, Paulino refere-se ao empenho dos governos de sua época "em difundir as luzes por todas as camadas da população" (Moacyr, 1937, p. 27).

A consigna do "ensino livre", entretanto, já estava colocada entre nós nessa época. Ela é proveniente do debate europeu em decorrência das diferentes estratégias de divulgação do ensino que lá se configuram. A expressão também resulta em diferentes significados que vão desde o entendimento da liberdade de pensamento nas instituições de ensino até a livre-oferta do ensino. ${ }^{15} \mathrm{~A}$ importação do tema, entretanto, tem aqui dentro as suas razões. Não são outras senão as já indicadas: os impasses na difusão do ensino em decorrência do baixo investimento público e o ambiente político de radicalização antipoder que se confunde com antagonismo às intervenções do próprio Estado.

$\mathrm{O}$ projeto de lei educacional encaminhado à Assembleia Geral por Paulino de Souza em 1870 é interessante de ser analisado justamente porque pode ser antevisto como um ponto de inflexão entre duas épocas, aquela configurada pelo Decreto Couto Ferraz e a que irá constituir-se como um novo paradigma de política de educação: o Decreto Leôncio de Carvalho, de 1879.

$\mathrm{O}$ relatório do ministro dirigido à Assembleia Geral em 1869 afirma: "Tendo em muito a iniciativa

\footnotetext{
${ }^{14}$ Ver especialmente parte 2, cap. 1.

${ }^{15}$ Para os diferentes significados da expressão "ensino livre",
} ver Barros (1986, parte 2, cap. 1). individual, seguiria eu nesta parte a doutrina da inteira liberdade de ensino, se a observação não tivesse demonstrado que só com o tempo, aturada aplicação, preparo especial e sobretudo gosto se podem alcançar bons professores" (idem, p. 98). É interessante notar a preocupação em responder à questão da "liberdade de ensino", demonstrando que ela já está na ordem do dia. E ele o faz relativizando a doutrina liberal diante da especificidade da função educacional, qual seja entendendo que sem investimento estatal nessa obra de longa formação do professor não haverá bom ensino. Tal argumento revela o quanto ele ainda está pautado pelo paradigma do velho decreto de 1854 , que também por aí justificou a intervenção estatal. Naquele mesmo relatório, Paulino prossegue:

\footnotetext{
Em todos os países os homens que se têm encarregado de dirigir e organizar o ensino público não se deixaram levar somente pela teoria, mas aprofundado o gênio da nação, esclarecidos por longa e bem aproveitada experiência, assentaram o sistema que mais convinha às circunstâncias peculiares e fizeram convergir para a sua completa execução todos os auxílios que puderam deparar. (idem, p. 99)
}

Agora, podemos destacar dois aspectos nos argumentos de Paulino de Souza: 1) um argumento antidoutrinário, que quer levar em consideração a experiência e as especificidades da nação; trata-se de fundamento que vem pautado por uma linha de raciocínio que, de modo geral, marcou o Partido Conservador, pelo menos desde o velho Visconde de Uruguai: a exigência de traduzir a doutrina para as particularidades da nação; 2) outro argumento que quer descobrir um caminho novo para a expansão do ensino, qual seja uma educação expandida não apenas pelas escolas regulares, mas para além delas, através da utilização de todos os recursos que a sociedade ofereça. Mais adiante, no relatório, ele especificará quais os recursos: salas de asilo, escolas de infância desvalida, escolas noturnas, escolas de domingo, escolas de fábrica, escolas de verão, escolas ambulantes etc.

O último argumento cumpre a dupla função: a de se preocupar com a expansão da educação ao povo, 
mas também a de adequar a escola às diferenças sociais e às circunstâncias da vida, ainda que não se faça estritamente pela iniciativa pública. Trata-se de argumento novo, pois até então prevalecia como recurso de expansão do ensino a estrita iniciativa pública ou a iniciativa particular, com ou sem subsídio público, devidamente regulamentada e fiscalizada. O projeto de Paulino de Souza não abre mão da fiscalização pública estrita, comprometido que é com o paradigma de 1854 , e até propõe novas formas de fiscalização, mais profissionalizadas, não mais no velho esquema de utilização de políticos para o preenchimento da função pública, porém introduz um critério novo porque se utiliza de vários recursos sociais já existentes, abrindo mão de uma velha reivindicação dos ministros que ocuparam o cargo nos gabinetes anteriores: a construção de prédios próprios para a educação, ainda que tal aspiração sempre fosse emperrada pela exiguidade das verbas públicas para o setor.

Ainda no relatório de 1869, Paulino de Souza começa a expor a situação do ensino na capital do Império. Antes de fazê-lo, afirma:

Dos três ramos da instrução pública, a primária é sem dúvida a mais interessante, pois que, além de ser condição essencial dos outros dois, se refere à máxima parte da população. A Constituição garantiu-a a todos os cidadãos. O esforço empregado pelos legisladores e pelo governo para distribuí-la convenientemente a todas as classes não é mais que cumprimento de uma promessa solenemente feita por ocasião de formar-se o Estado e assentarem-se as bases da nossa comunhão política. (idem, p. 100-101)

Na conclusão do relatório, ele recorre a um argumento que de certa forma marcou o Partido Liberal em sua crítica à centralidade monárquica. Diz Paulino:

\footnotetext{
Não é fechando tudo nas próprias mãos ou nas dos seus agentes imediatos e isolando a ação de cada um que o governo conseguirá despertar o concurso dos cidadãos, sem o qual o seu impulso se vai amortecer ante o indiferentismo. [...] Não temos o hábito das associações, não existe no país a iniciativa individual para fins de utilidade pública. (idem, p. 105-106)
}

$\mathrm{O}$ argumento, se por um lado reflete a tradição conservadora de pensar o que nos especifica, por outro afina-se com o que mencionamos antes, a crítica liberal ao centralismo monárquico. Tal concessão aos liberais nos parece indicativo do novo tempo, de liberais afastados do poder, mas cujos temas e proposições estão na ordem do dia. Não coincidentemente se seguirá ao Gabinete Itaboraí, do qual Paulino é ministro, o de Paranhos, o primeiro Mauá, também conservador, que no entanto implementará inúmeras consignas políticas da tradição liberal, incluindo principalmente a questão da emancipação dos escravos - a Lei do Ventre Livre (1871).

No relatório de 1870 à Assembleia Geral, Paulino de Souza revela as suas simpatias ao projeto de universidade conhecido então como "universidade alemã", sabidamente uma universidade de caráter público. Mais uma vez aqui se expressa o compromisso do autor com um Estado positivo na construção universitária, não apenas na sua regulamentação. Como concessão aos novos tempos, porém, preconiza a "frequência livre" no terceiro grau; no entanto, sem regulamentações ou mesmo incentivos para a construção de "escolas livres", como posteriormente serão estabelecidos pelo Decreto Leôncio de Carvalho.

Um aspecto final a destacar nesse último relatório serve-nos também para registrar as contingências de um tempo. Trata-se da questão da obrigatoriedade da frequência escolar no ensino elementar. Considerase que a obrigatoriedade está dada desde o Decreto Couto Ferraz, porém argumenta Paulino pragmaticamente: "Não se pode exigir que os pais e tutores de menores mandem os filhos e pupilos às escolas sem que estas existam efetivamente em lugar onde possam comodamente serem frequentadas" (idem, p. 117). Propõe-se, então, a "criar novas escolas onde forem necessárias [...] [para poder regulamentar] de modo prático o dispositivo do regulamento de 1854 sobre obrigação escolar e de outras várias ideias de incontestável proveito consignadas no mesmo regulamento" (idem, ibidem).

O argumento de Paulino não revela apenas comprometimento com o velho paradigma naquilo que ele 
explicita, mas na própria concepção de "frequência obrigatória" do ensino elementar, de uma obrigatoriedade de princípio mas dependente das possibilidades de sua implementação, bem nos marcos de como foi formulado lá em 1854, sequer estabelecendo a faixa de idade de obrigatoriedade escolar. A importância de destacar o último aspecto está na identificação da ruptura com tal concepção de obrigatoriedade que se colocará logo a seguir, quatro anos após, quando se formula outro projeto de lei, o João Alfredo. Verificarse-á que aí já ingressamos em outra matriz de política pública de educação.

João Alfredo é ministro dos Negócios do Império de um gabinete conservador, o do Visconde de Mauá, de 7 de março de 1871. O gabinete substituiu o de São Vicente, de curta duração, que por sua vez substituiu o Gabinete de Itaboraí, que é aquele cuja ascensão por vontade do Imperador causou a crise de 1868, por conta do rompimento do largo período de estabilidade liberal. Os intuitos emancipacionistas do Imperador, renovados após o término da Guerra do Paraguai, estão na raiz da queda do gabinete conservador de Itaboraí em 1870. Portanto, a despeito de continuarem os gabinetes que se seguiram na esfera do Partido Conservador, com São Vicente e depois Mauá, o quadro político é bem distinto daquele que inaugurou a situação conservadora de 1868. Como diz Joaquim Nabuco, são políticos de outra estirpe. ${ }^{16}$

Os argumentos do ministro João Alfredo encaminhados à Assembleia Geral Legislativa, no ano de 1871, sobre o projeto de reforma do ensino primário que irá encaminhar futuramente já trazem uma novidade fundamental que o distancia da velha herança do regulamento de 1854. Tratar-se-ia para ele de adotar a "liberdade de ensino" entendida como dispensa de avaliação intelectual para quem a ofereça, mantendo-se apenas como restrição "a obrigação de darem provas de sua moralidade os que a ele se dedicarem" (idem, p. 136). As razões pelas quais devem ser suspensas as exigências do Estado de oferta do ensino por particulares são de ordem prática. Os exames de capacidade

\footnotetext{
${ }^{16}$ Ver, a respeito do período, Nabuco (1997, p. 797-814).
}

profissional "nem sempre dão a melhor prova de suas habilitações reais" (idem, ibidem). Conhecer as matérias que versam no currículo não é o bastante; "há outra condição essencial: a de saber ensinar, qualidade que só se pode adquirir pela ciência do método e pela prática" (idem, p. 137). A outra razão é a ausência de professores habilitados, "sobretudo em relação às localidades de pouca população e riqueza" (idem, ibidem), o que impede a possibilidade de ofertar escolas com a existência da antiga regulamentação. São todas, portanto, razões pragmáticas, da ordem das "experiências vitais".

No que se refere à questão da obrigatoriedade de frequência no ensino elementar, nesse primeiro relatório, o argumento ainda é o mesmo que fora com Paulino de Souza e toda a tradição do regulamento de 1854: ela já está prevista no Couto Ferraz, mas a sua aplicabilidade dependeria de melhorar a oferta pública. Porém, no segundo relatório, o do ano de 1872, introduz-se um argumento novo sobre a questão da obrigatoriedade: o dever do Estado de oferecer deve ser acompanhado do dever de receber. A formulação de João Alfredo é de que "há íntima ligação entre estes dois deveres" (idem, p. 139). O argumento é novo porque desloca para o campo da sociedade o dever da frequência, cabendo ao Estado a regulamentação, a fiscalização e a punição aos responsáveis pela infrequência.

A rigor, os dois deveres - o de ofertar o ensino e o de frequentá-lo - são transferidos para a sociedade, pois, com o "ensino livre", a expansão da oferta de ensino é transferida basicamente para o particular. Configurase aí a "ligação íntima entre os dois deveres". Ela é fundada na expectativa de que a obra de difusão da instrução primária conte com a ajuda de donativos de particulares, bem como de suas iniciativas, propondo "lançar mão de algum meio de exaltar a opinião pública, até que pouco a pouco tome ela de per si a dianteira" (idem, p. 141).

Percebe-se, então, que o paradigma agora é outro, pois instala-se a ideia de que a iniciativa educacional é fundamentalmente da sociedade, não mais do Estado, ou seja, daqueles que possuem meios de oferecê-la. No antigo regulamento também havia o subsídio público para o ensino particular, mas a iniciativa fundamental 
era pública e o subsídio era complementação. Além disso, o poder público, provincial ou municipal, exigia sempre uma contrapartida ao recebimento do subsídio: o recebimento de matrículas de alunos pobres. Agora, desregulamenta-se a oferta e instiga-se a subvenção sem qualquer outra condição, exceto em meio rural, onde, existindo professores particulares, pode o governo contratar com estes "mediante gratificação razoável [...] o ensino de meninos pobres da vizinhança" (idem, p. 151).

Outra característica que distingue o projeto de lei de João Alfredo apresentado à votação à Assembleia Geral em 1874 da regulamentação anterior diz respeito novamente à forma de entendimento da questão da obrigatoriedade de frequência no ensino elementar. Como já previra o relatório do ministro dois anos antes, a questão da obrigatoriedade é rigorosamente regulamentada, estabelecendo-se a faixa de idade completa (de 7 a 14 anos) e estendendo a obrigatoriedade a 18 anos para os que não tenham recebido o ensino primário, em existindo "escolas de adultos" nos lugares. Diga-se que o cumprimento da obrigatoriedade da frequência exige existência de escola pública ou subsidiada num raio de até 1,5 a 2 quilômetros de distância da moradia do aluno.

Além da regulamentação estrita da frequência escolar, há no projeto de lei a punibilidade aos pais ou tutores, mas também aos patrões que tenham empregados na faixa de 15 a 18 anos que não tenham tido a oportunidade de cursar o ensino elementar na idade adequada. A questão da punibilidade pela infrequência escolar não é novidade nas legislações provinciais ao longo do Império. Aqui, no entanto, há um rigor muito mais acentuado na regulamentação, revelando talvez o entendimento de que a razão pelo estado deplorável da situação educacional do país esteja situada não tanto na minimização da oferta pública, mas na "negligência" do povo. Trata-se assim de um deslocamento na responsabilização.

Finalmente, o último aspecto que destacamos do projeto de lei de 1874 é bem indicativo da matriz político-cultural e da temporalidade que o perpassa. Trata-se de um aspecto absolutamente inovador ao tempo, pois refere-se à criação de verba municipal para educação profissional, assim como o estabelecimento de índice orçamentário no município para o cumprimento da obrigação. A previsão do projeto é nova, como se disse, porém o que há de mais interessante na proposta é que o índice busca fixar o "teto" do valor aplicado, ao invés do piso, como um critério contemporâneo indicaria. Também em termos inovadores, introduz-se um item no projeto em que o governo da União deverá contribuir com a complementação orçamentária de municípios que não consigam, com seus rendimentos (ainda que associados com outros municípios), manter a escola profissional, porém é necessário, para obter a colaboração da União, que cheguem pelo menos a dois terços dos gastos previstos. Menos do que isso, não há colaboração.

Portanto, nos dois critérios, o do orçamento municipal pelo teto e o do princípio de colaboração da União pelos que podem mais, a pretensão não é de atingir a todos ou mesmo ajudar os municípios mais carentes. Isso nos parece bastante indicativo de um tempo histórico em que a educação não é compreendida como um direito dos indivíduos, portanto não extensivo a todos, mas como algo que é entendido como relevante na formação de uma sociedade civil, cuja amplitude será sempre relativa. Há, sim, a preocupação com a incorporação de indivíduos à sociedade civil, porque aí estaria a base civilizatória da nação, que de alguma forma se comunica com a legitimação da representação política no moderno Estado que se pretende ser; entretanto, tal ampliação se dá nos limites possíveis, porque não é a abrangência que define o caráter da legitimidade requerida. Têm-se assim os marcos da temporalidade.

\section{Metamorfose de uma representação sobre o povo: da incúria à insuficiência cívica}

Após o longo processo genealógico que antecede o último regulamento de educação do Império, retornamos ao decreto, agora com mais elementos para pensá-lo e para demonstrar nossas hipóteses. Pode-se, na genealogia proposta, distinguir três fases históricas, sendo a segunda uma fase de transição. As 
características da primeira fase, a do Decreto Couto Ferraz, de 1854, são as de um Estado fortemente proponente da educação, visto ser o caráter ativo muito mais pela regulação e fiscalização que propriamente pelo investimento público, embora este seja também instigado por ministros e políticos em geral comprometidos com o entendimento do papel da educação na formação da sociedade civil. Ali se estabeleceu pela primeira vez uma sistemática de inspetoria do ensino, bem como uma estruturação funcional da educação via ordenação de suas instâncias. Deu-se o controle sobre o ensino privado, especialmente pelas exigências de exame de capacidade intelectual dos candidatos a mestre. Definiu-se a obrigatoriedade escolar, ainda que de forma frouxa, sem estabelecer sequer a faixa de idade. Outro aspecto fundamental para caracterizar essa fase histórica é a atribuição ao Estado da responsabilidade na construção educacional. A educação é obrigatória, porém o princípio somente se aplicará com o aprimoramento da oferta estritamente pública ou com apoio público. Nesse sentido, a obrigatoriedade não é uma dimensão crucial a ser regulamentada, pois a responsabilização é institucional.

Esses aspectos já são o bastante para definir o paradigma do projeto de educação que se configurou naquele contexto, deixando claro o caráter ativo do Estado em sua pretensão de alargamento e aprimoramento da sociedade civil, da qual sai a sociedade política, que é a garantia de representatividade legítima da nação moderna. Conservadores ou liberais assim entendem o papel da educação na construção da cidadania, cuja amplitude é sempre relativa, como dissemos, porque não se trata de um direito individual, mas uma exigência pública de aprimoramento civil.

A fase histórica da transição, a do projeto de lei de Paulino de Souza, a rigor pertence ao primeiro período. A matriz que o preside ainda é o Decreto Couto Ferraz. Isso por duas razões: 1) embora já se refira ao "ensino livre", e até proponha a livre-frequência no terceiro grau, a responsabilização fundamental da oferta é do Estado; 2) em decorrência do primeiro argumento, a concepção de obrigatoriedade segue as mesmas marcas daquele decreto: ela é proposta, mas sujeita às possibilidades da oferta pública ou comissionada. Paulino de Souza é um chefe do Partido Conservador e dos mais fiéis adeptos da centralidade monárquica, que, na esfera da educação, se confunde com o papel do Estado na oferta e regulação estrita do setor.

Não obstante, trata-se de um período de transição. As características de mudança da política estão presentes também nesse projeto de lei. Uma de suas expressões é a própria proposta de expansão da escolaridade não apenas via escolas regulares, mas através de todo tipo de recursos existentes na sociedade, como já se especificou. O caminho proposto contraria a tradição sempre reposta pelos ministros dos Negócios do Império, embora pouco atendida pelas Assembleias, de exigir a construção de prédios escolares próprios, adequados à educação. Paulino fez uma genial adequação da tradição ideológica do Partido Conservador, de sempre buscar o ajustamento das políticas ao contexto nacional antes de levar ao pé da letra os termos da doutrina, com as exigências do novo tempo, expresso especialmente pelos liberais, que se angustiam com as amarras da legislação. A utilização dos recursos já existentes na sociedade, instigados e comissionados pelo poder público, não deixa de ser uma alternativa nova à expansão da escolaridade, ainda que tutelada pelo Estado.

Finalmente, a última fase, antes mesmo do Decreto Leôncio de Carvalho, já se configurando no projeto de lei de João Alfredo. Como se disse, a novidade do projeto é a incorporação da ideia do "ensino livre". Embora houvesse à época muita controvérsia quanto ao que se entende por essa consigna, o que fica patente no projeto do ministro é a compreensão de que se trata da livre-oferta em todos os níveis de ensino. Para o terceiro grau, também significará a livre-frequência. Trata-se, assim, de assumir que o principal entrave à expansão do ensino é o excesso de regulamentação pública.

Mas há que se destacar que os argumentos usados nos relatórios do ministro para justificar a adoção do novo princípio não são doutrinários; eles decorrem de razões práticas, tais como: a inadequação dos exames intelectuais, como previsto no antigo decreto, para bem avaliar o bom professor; a ausência de professores habilitados no interior, impedindo que essas popula- 
ções possam ter acesso ao ensino; as exigências de multiplicação das escolas em geral.

O outro aspecto que destacamos mais acima como característica desse projeto de lei refere-se à questão da obrigatoriedade da frequência na escola elementar. Embora a obrigatoriedade esteja prevista desde o antigo decreto, nunca teve o acento que assumiu no projeto de João Alfredo. A obrigatoriedade na velha matriz era dependente do crescimento da oferta, especialmente pública; agora isso já não aparece como entrave porque se pretende a ampliação da oferta via iniciativas da sociedade, desatreladas em boa medida da regulamentação pública, embora não da fiscalização. A nova ênfase na obrigatoriedade - evidenciada também no argumento do ministro de atribuir a pais, tutores e patrões a "negligência" para com a educação - revela um deslocamento na responsabilização da situação educacional do país: já não são as políticas de Estado o fulcro da acusação, mas a negligência daqueles que na sociedade teriam a responsabilidade. É nesse sentido que destacamos o elo entre os dois aspectos do projeto de João Alfredo que caracterizam a nova matriz: "livre-ensino", entendido como desregulamentação da oferta, acompanhado de regulação estrita da obrigatoriedade de frequência no ensino elementar. Aqui já se esboça o ideal de que a iniciativa educacional não é estritamente da esfera pública, mas deve contar cada vez mais extensamente com a iniciativa da sociedade.

O Decreto Leôncio de Carvalho é herdeiro dessa nova matriz formulada originalmente pelo projeto de João Alfredo. No entanto, a ênfase do argumento agora é outra. Leôncio de Carvalho é ministro dos Negócios do Império de um gabinete liberal, que somente retornou ao poder após 11 anos de afastamento. Seu discurso é mais ortodoxamente doutrinário: o "livre-ensino" decorre da exigência do livre-pensamento e da livre-oferta. O primeiro é uma exigência do tempo, aqui e alhures, que não pode mais admitir qualquer doutrina oficial restringindo o livre-pensar; o segundo, porque somente a livre-escolha poderá garantir a melhor escolha. ${ }^{17}$

${ }^{17}$ As afinidades teóricas de Leôncio de Carvalho parecemse dar com Herbert Spencer. Pela teoria do Estado de Spencer,
No terceiro grau, a consigna do ensino livre tem várias implicações, como a promoção de "associações de professores para a fundação de cursos particulares, que mediante certas condições de garantias passam a obter do governo a qualidade de faculdades livres com autorização para conferir graus acadêmicos" (Moacyr, 1937, p. 172, ortografia atualizada). Outra consequência é a frequência livre, o que resulta numa reforma geral do sistema de ensino oficial. "O velho regime de faltas, lições e sabatinas, que ainda vigora nas academias, merecem ser abolidos" (idem, ibidem). Aprofundando ainda mais as consequências do novo regime, propõe-se o fim do sistema de seriação nesse grau de ensino, sob o argumento último de "levar-se em conta a graduação infinita, que, sob o ponto de vista moral e o físico vai de indivíduo a indivíduo [...]" (idem, p. 174). A frequência livre, bem como a suspensão do sistema de seriação anual, estende-se ao segundo grau, incluindo o externato do Colégio Pedro II.

Tudo isso revela o grau de radicalização doutrinária do Decreto Leôncio de Carvalho. Mas para o que aqui nos interessa mais de perto, a "instrução primária", a questão relevante é a obrigatoriedade de frequência. Como já se disse, quando nos referimos ao projeto de João Alfredo, ela segue a par com a livreoferta de ensino precisamente porque parte do suposto de que já não haverá o antigo problema da oferta reduzida de ensino, na medida em que ela crescerá, pois estará desamarrada das regulamentações oficiais.

Mas, além dessa dimensão de expectativa de crescimento da oferta, há outro aspecto no argumento que merece destaque. Trata-se de algo que já apareceu no projeto de João Alfredo, de atribuir aos responsáveis

a maioria das regulamentações é nociva, pois tem origem numa sociedade militar. Como a guerra se tornaria obsoleta na sociedade industrializada, inúmeras funções governamentais deveriam ser relegadas à iniciativa privada. Elas seriam "pecado dos legisladores" ou se tornariam desnecessárias com a marcha da evolução. Entre as funções estatais a serem suprimidas, estariam todas as formas de regulamentação da indústria, a caridade pública, o custeio da educação. Ver, a respeito, Sabine (1964, p. 701). 
pelas crianças a culpa pelo estado de precarização da educação popular. Agora o argumento aparece não en passant, como naquele, mas com todas as letras.

\footnotetext{
Em face da incúria que se observa nas classes inferiores da nossa sociedade no tocante à educação da infância, não é lícito ao Estado cruzar os braços e ver impassível crescerem na ignorância, sem o mais elementar aprendizado, privados da mais ligeira noção de direitos e deveres, milhares de crianças, a quem mais tarde está reservado um papel na vida social e política da nação. (idem, p. 182, ortografia atualizada, grifo nosso)
}

Tem-se, assim, nos argumentos do Decreto Leôncio de Carvalho, considerável mudança conceitual na natureza da crítica. No que diz respeito às instituições, faz-se uma crítica radical a toda norma existente. As críticas implícitas ou explícitas formuladas em projetos de lei anteriores são sempre pontuais nesse ou naquele aspecto, buscando o aperfeiçoamento institucional, como em Paulino de Souza, quando pretende profissionalizar a inspeção escolar. Mesmo João Alfredo, que mais se aproxima da matriz do último decreto, apesar de ter uma crítica institucional mais severa, tem argumentos que se fundam de modo geral nas "experiências vitais". Agora, com Leôncio de Carvalho, a natureza da crítica institucional é diferente. Ela é da esfera da doutrina, da "imagem de mundo". Nessa crítica, atribui-se às "classes inferiores" a "incúria", a elas imputando a precariedade educacional do país. Ora, isso altera a tradição do Império de alterar a legislação para melhor adaptá-la à realidade, seguindo o princípio das reformas eleitorais ao longo do período, como se disse acima. A ideia nova, de incúria do povo, muda o vilão da história.

Trata-se, assim, nos termos de Dilthey, de uma nova "visão de mundo". Para avançar na nossa justificação da nova "visão de mundo" em Leôncio de Carvalho, recorremos ainda aos seus termos argumentativos, buscando neles um novo registro de tempo histórico. Um aspecto que destacamos na exegese feita sobre os textos os quais revelam a matriz do Decreto Couto Ferraz, e que ainda aparece no projeto de Paulino de Souza de 1870, é o argumento da ampliação da educação à população livre por razões políticas, qual seja a exigência de formar o eleitor que comporá a representação da nação. Tratava-se, assim, de formar uma cidadania civil e política, como de resto se constituiu a marca da ampliação da condição cidadã ao longo do século XIX, como indica o estudo do caso clássico inglês (Marshall, 1967). É interessante notar como o argumento já não aparece no projeto de João Alfredo (1874). A tônica dada por tal projeto ao ensino profissional, inclusive de adultos, já deixa implícito que a justificação para a expansão da educação popular parece dar-se estritamente para oferecer condições de trabalho. ${ }^{18}$

Ora, o Decreto Leôncio de Carvalho, no entanto, além de não fazer qualquer referência ao aspecto político como justificador da expansão educacional, substitui-o por um argumento estritamente social: "a educação, diminuindo consideravelmente o número de indigentes, dos enfermos e dos criminosos, aquilo que o Estado despende com as escolas poupa em maior escala com asilos, hospitais e cadeias" (Moacyr, 1937, p. 183). Ainda no mesmo diapasão social, porém incluindo a razão dos de cima da escala social, atribui como justificação até mesmo "uma questão de defesa pessoal", fazendo referência aos argumentos de uma comissão escolar em Connecticut, nos EUA, diante do espanto da "presença de grande número de meninos abandonados à ignorância, criados em contato com todos os vícios e expostos à influência dos mais perniciosos exemplos" (idem, ibidem). ${ }^{19}$

Há uma visível mudança das razões justificadoras da expansão educacional. Deixam de ser razões

${ }^{18}$ Tavares Bastos (s.d.), em A Província (1870), justifica a ampliação da educação sob o duplo argumento: o da qualificação da força de trabalho e o da formação moral do cidadão. Nesse sentido, o seu pensamento, no que diz respeito à educação, encontra-se contido no paradigma Couto Ferraz. É justamente a dimensão moral como justificativa de expansão da educação que começa a se perder com o novo paradigma.

19 Leôncio de Carvalho também prioriza o ensino profissional, porém coloca-o numa regulamentação à parte do decreto de 1879 . 
políticas e passam a ser razões sociais, sejam elas assistenciais às camadas pobres da população, sejam as ameaças que a situação de miséria do povo possam trazer aos segmentos sociais privilegiados. O que isso pode indicar sobre as modificações a respeito das representações vigentes no campo da política, mais especificamente sobre as representações da cidadania?

A resposta é difícil no âmbito que nos propusemos neste trabalho, que é de nos limitarmos a uma hermenêutica das regulamentações educacionais e suas justificativas. Entretanto, podemos especular sobre a suspensão da íntima relação entre ética e política expressa pela última regulamentação da educação no Império, relação essa que perpassou o conceito de cidadania, desde suas origens gregas, até sua apropriação moderna europeia, sustentando a legitimação do poder do Estado, na linha interpretativa de Koselleck (1999). ${ }^{20}$

Também entre nós a relação existiu desde os primórdios da nação independente, ainda prevalecendo nos primeiros 20 anos da segunda metade do século XIX, como indicam os argumentos justificadores da educação quando do predomínio da matriz do Decreto Couto Ferraz. Retomando a questão, se a preocupação com o alargamento da sociedade civil em termos de participação política já não se constitui em elemento fundamental da legitimação do poder no projeto de nação das elites governantes ao final do Império, como expressou o Decreto Leôncio de Carvalho, em que consistia a nova concepção de cidadania no projeto de nação que passou a vigorar?

Diga-se que a ideia de uma cidadania fundada no contrato entre iguais e que realiza a sua condição social não estritamente pela política, mas pelo exercício de sua liberdade individual, qual seja seus direitos de ir e vir, de pensamento, de religião, de propriedade etc. já fora formulada, lá no início do século XIX, por Benjamin Constant (1980). Ocorre que esse autor, com certeza inspirador da nossa primeira Constitui-

${ }^{20}$ Sobre a relação entre ética e política nas concepções do moderno Estado europeu, ver especialmente Koselleck (1999, cap. 2). ção, formula como um dos poderes da monarquia constitucional o "poder representativo da opinião", que se constitui como uma assembleia eletiva (Constant, 1872). Sua teoria quer-se opor a uma concepção jacobina de poder, que compreende a política como expressão direta do voto dos cidadãos. No contraponto, Constant estabelece a política como representação. Nesse sentido, política como participação no poder, via representação, e direito civil não se opuseram naquela concepção primeva. Ao final do século XIX, a doutrina liberal inglesa, de forte influência no continente europeu, acentua o liberalismo político para incorporar o fato histórico da progressiva extensão do direito de voto, ocorrida ao longo do século XIX; e transformase no sentido de atender a um papel mais positivo do Estado em decorrência do crescente poder político da organização do trabalho, em sua luta contra os efeitos sociais de um industrialismo sem freios, apoiado por uma opinião pública que, por motivos éticos, religiosos ou humanitários, estava disposta a apoiar essas lutas e reivindicações (Sabine, 1964, p. 702).

O que se passou entre nós, nesse final do século XIX, vai por caminhos completamente distintos. Se a tradição do Império, desde a visão civilizatória de Bernardo Pereira de Vasconcelos, lá nos primórdios do país independente, foi de justificar a ampliação da educação como exigência de formação de uma sociedade civil, que de alguma forma se comunicaria com a sociedade política, o argumento agora usado por Leôncio de Carvalho é puramente social. A nossa compreensão é de que se alterou fundamentalmente nesse final do Império a noção de cidadania que o perpassou. Por mais que se pense que o ideário nascido com Bernardo Pereira de Vasconcelos esteja comprometido com tudo aquilo que é designado pelas palavras civilização, instrução, educação, cultura etc., e não propriamente fundado numa concepção de individualidade livre e participativa, elemento essencial na formação da sociedade e Estado modernos, como se configura doutrinariamente no liberalismo do final do século XIX, ainda assim ali está colocada uma relação entre educação e política. Foi justamente essa tradição que se perdeu ao final do Império. Trata-se agora de culpar 
o público afetado pela educação obrigatória, inverter a ordem do protagonismo social - não mais o Estado, mas a iniciativa privada - e justificar a ampliação educacional pela carência social da população-alvo. Houve uma ruptura entre representação política e legitimidade social. O que se tem agora é uma imputação negativa dessa ampliação de legitimidade. Esta agora é vista sob o ângulo da qualidade social e do acesso às "luzes" civilizatórias. Como se disse antes, isso não passou despercebido ao tempo da reforma eleitoral de 1881. Ao excluir os analfabetos da participação eleitoral, no dizer de José Bonifácio, o moço, deputado por São Paulo, retirou-se o sujeito da oração política. Enfim, abdicou-se de quem poderia dar substância social ao jogo político.

José Murilo de Carvalho (1999, p. 92) bem percebeu a redefinição da cidadania no final do Império, atribuindo a ela a exigência de dificultar a participação eleitoral dos libertos. Nossa leitura, no entanto, é outra. O que ali ocorre já se vem configurando ao longo da década de 1870. No âmbito da política de educação, como procuramos demonstrar, os impasses da ampliação da escolaridade no velho paradigma e a opção por nova matriz de ordenação do setor são bem indicativos da mudança valorativa na compreensão do sujeito-alvo dessa política. Já não se trata do povo que aqui temos, como de certa forma se pautou a política ao longo do Império, ao fazer a crítica das instituições para melhor captar a nossa realidade. Atribui-se agora uma imanência negativa à realidade da nação e ao povo que a constitui. Se o argumento inicialmente é pragmático, voltado para o reconhecimento das dificuldades, a seguir torna-se doutrinário, visão de mundo, descolandose do contexto para tornar-se concepção de indivíduo e de cidadão. Não é, no entanto, um abstracionismo ideológico justificador de políticas elitistas, como na interpretação de José Murilo de Carvalho. Trata-se de uma visão de realidade. É justamente isso que a torna uma herança persistente na República. ${ }^{21}$

${ }^{21}$ A ideia de herança aqui formulada nos conduz à de permanência. Mas o que permanece? Uma solução teórica possível seria aquela apontada por Koselleck com a criação de duas categorias
A República transmutará a ideia de incúria do povo em insuficiência cívica. A discussão que se trava na Constituinte de 1891 a respeito da obrigatoriedade escolar já é bem indicativa dos caminhos que se seguirão. Carlos Roberto Jamil Cury chama a atenção para duas ordens de argumentos que lá se utilizaram: a pragmática, relegando a questão aos estados; e a doutrinária, compreendendo o indivíduo como um ser genérico, universal, desvinculado de qualquer meio social, dotado de uma virtus que deve conduzi-lo (Cury, 2001). Tornar-se cidadão é um esforço pessoal. É essa ideia abstrata de indivíduo, fruto de uma concepção de cultura civilizatória universal, que nos faz comparáveis a outros povos, dos quais saímos devedores pela carência, como já se disse. Universalismo e imanência combinam-se para estabelecer uma comparação negativa do que somos.

Para finalizar, digo que uma das pretensões deste trabalho é trazer uma contribuição da história da educação para um tema sobre o pensamento social brasileiro já bem debatido pelos historiadores e

históricas: "espaço de experiência" e "horizonte de expectativas". Trata-se, para o autor, de duas categorias meta-históricas que indicariam uma condição humana universal "sem a qual a história não seria possível, ou não poderia sequer ser imaginada" (Koselleck, 2006, p. 308). A primeira remete ao "passado atual, aquele no qual acontecimentos foram incorporados e podem ser lembrados" (idem, p. 309). A segunda é "futuro presente, voltado para o ainda não, para o não experimentado, para o que apenas pode ser previsto" (idem, p. 310). Se algum paralelo é possível entre essas categorias de Koselleck com as de Dilthey, que aqui trabalhamos, experiência vital e imagem de mundo, diríamos que a "visão de mundo" herdada pela República é a persistência no novo contexto da duas dimensões categorizadas por Koselleck, qual sejam um passado que ainda se faz presente como memória e um futuro presente que se expressa como "horizonte de expectativa" contido numa “imagem de mundo". A pretensão de Koselleck (idem, p. 308) no uso dessas categorias é dar conta do "tempo histórico, pois elas entrelaçam passado e futuro". Também essa foi a nossa pretensão ao trabalharmos com as categorias de Dilthey, indo para além do iluminismo do autor. 
cientistas sociais. ${ }^{22}$ Trata-se justamente de historiar uma "visão de mundo" que tem o seu fundamento no final do Império, ali constituindo uma representação imanente e negativa do que somos, no contraponto a formulações de viés romântico (Tobias Barreto e Sílvio Romero, entre outros) que melhor positivaram a nossa herança (Nascimento, 1999). Talvez se possa dizer que ali se formulou uma primeira versão das teorias que mais tarde irão procurar a especificidade do brasileiro, a ponto de absolutizar a nossa experiência de nação, retirando-nos do seio das sociedades humanas em geral, atribuindo-nos uma congênita impossibilidade de constituir uma moderna sociedade civil por conta da prevalência, entre nós, de laços de compadrio, de pessoalidade, de tudo que é próprio do mundo privado.

\section{Referências bibliográficas}

BARROS, Roque Spencer Maciel de. A ilustração brasileira e a ideia de universidade. São Paulo: EDUSP/Convívio, 1986.

BARROSO, José Liberato. A instrução pública no Brasil. Pelotas: Seiva, 2005.

BASTOS, A. C. Tavares. A Província. São Paulo: Nacional; Brasília: INL-MEC, s/d.

BOSI, Alfredo. Dialética da colonização. São Paulo: Companhia das Letras, 1992.

CÂMARA DOS DEPUTADOS. Annales do parlamento brazileiro. Terceiro anno da Décima-Quinta Legislatura. Sessão de 1874. Rio de Janeiro: Tipographia Imperial e Constitucional de J. Villeneuve \& C., 1874. tomo III.

CARVAlHO, José Murilo de. Pontos e bordados: escritos de história e política. Belo Horizonte: Editora UFMG, 1999.

COLLECÇÃO DAS LEIS DO IMPÉRIO DO BRASIL. Decreto n. $1.331 \mathrm{~A}, 17$ de fevereiro de 1854. tomo 17, parte 2, secção 12a . COLLECÇÃO DE LEIS DO IMPÉRIO DO BRAZIL DE 1879. Decreto n. 7217, 19 de abril de 1879. tomo XXVI, parte I, tomo XLII, parte II.

CONSTANT, Benjamin. Cours de politique constitutionnelle. Paris: Guillaumin, 1872.

${ }^{22}$ Sobre esse debate nas ciências sociais e na historiografia brasileira, ver o excelente artigo de Ivan Vellasco (2009).
De la liberté chez les modernes. Paris: Le Livre de Poche, 1980.

CURY, Carlos Roberto Jamil. Cidadania republicana e educação. Rio de Janeiro: P \& A, 2001.

FARIA FILHO, Luciano Mendes de. Instrução elementar no século XIX. In: LOPES, Eliane Marta et al. (Orgs.). 500 anos de educação no Brasil. Belo Horizonte: Prefeitura de Belo Horizonte/ Autêntica, 2000.

HEIDEGGER, Martin. Introdução à filosofia. São Paulo: Martins Fontes, 2008.

HOLANDA, Sérgio Buarque de. História geral da civilização brasileira. São Paulo: DEL, 1972, v. 5, tomo II.

KOSELLECK, Reinhart. Uma história dos conceitos: problemas teóricos e práticos. Estudos Históricos, Rio de Janeiro, v. 5, n. 10, p. 134-146, 1992. Crítica e crise. Rio de Janeiro: EDUERJ/Contraponto, 1999. Futuro passado: contribuição à semântica dos tempos históricos. Rio de Janeiro: Contraponto, Editora PUC-Rio, 2006. LOCKE, John. Ensaio acerca do entendimento humano. São Paulo: Abril Cultural, 1973 (coleção Os Pensadores).

MARSHALL, T. H. Cidadania, classe social e status. Rio de Janeiro: Zahar, 1967.

MATTOS, Hebe Maria. Escravidão e cidadania no Brasil monárquico. Rio de Janeiro: Zahar, 2000.

MOACYR, Primitivo. A instrução e o Império (Subsídios para a história da educação no Brasil, 1854-1888). São Paulo: Nacional, 1937. v. II (Coleção Brasiliana).

NABUCO, Joaquim. Um estadista do Império. 5. ed. Rio de Janeiro: Topbooks, 1997.

NASCIMENTO, Jorge Carvalho do. A cultura ocultada. Londrina: Editora UEL, 1999.

ROCHA, Marlos Bessa Mendes da. O Decreto Couto Ferraz num contexto de transformação da res publica. Comunicação no $\mathrm{V}$ Congresso Brasileiro de História da Educação. Aracaju, 2008.

SABINE, George H. História das teorias políticas. Rio de Janeiro: Fundo de Cultura, 1964.

SARTORI, Giovanni. A teoria da democracia revisitada. 2. As questões clássicas. São Paulo: Ática, 1994.

SCHWARZ, Roberto. Ao vencedor as batatas. São Paulo: Duas Cidades/Editora 34, 2000.

VASCONCELOS, Bernardo Pereira de. Bernardo Pereira de Vasconcelos: organização e introdução de José Murilo de Carvalho. São Paulo: Editora 34, 1999. 
VELLASCO, Ivan de Andrade. Clientelismo, ordem privada e Estado no Brasil oitocentista: notas para um debate. In: CARVALHO, José Murilo; NEVES, Lucia Maria Bastos. Repensando o Brasil do Oitocentos: cidadania, política e liberdade. Rio de Janeiro: Civilização Brasileira, 2009.

MARLOS BESSA MENDES DA ROCHA, doutor em educação pela Universidade de São Paulo (USP), é professor da Faculdade de Educação da Universidade Federal de Juiz de Fora (UFJF), atuando no Programa de Pós-Graduação em Educação. Publicações mais importantes: Educação conformada: a política pública de educação no Brasil (1930-1945) (Juiz de Fora: Editora da UFJF, 2000); Matrizes da modernidade republicana: cultura política e pensamento educacional no Brasil (Campinas: Autores Associados; Brasília: Plano, 2004). Pesquisa desenvolvida em 2007-2009, com financiamento da FAPEMIG: "Políticas de educação, escolarização e estratégias de nação: a transição Império/ República". Atualmente desenvolve outro projeto, também com financiamento da FAPEMIG, desdobrando a pesquisa anterior para as primeiras décadas republicanas.E-mail: marlos.bessa@ ufjf.edu.br

Recebido em setembro de 2009 Aprovado em janeiro de 2010 
Marlos Bessa Mendes da Rocha

O ensino elementar no Decreto Leôncio de Carvalho: "visão de mundo" herdada pelo tempo republicano?

O artigo aponta para o predomínio de uma ideia que surgiu ao final do Império no Brasil, a de incúria do povo, e que, na República que se seguiu, se transformou em insuficiência cívica desse mesmo povo. A ideia de incúria do povo não perpassou o Império; ela surgiu nos últimos 15 anos deste, mudando a velha matriz imperial de culpar o fracasso das políticas às falhas das instituições. Para demonstrar o predomínio dessa nova ideia nessa fase final do Império, que mudou o vilão da história, toma-se a política de educação na forma como se expressou no ministro Liberato Barroso e nos projetos de lei que são debatidos na Assembleia Geral do Império (Paulino de Souza e João Alfredo), bem como no DecretoLei Leôncio de Carvalho, sempre no contraponto com a tradição advinda do Decreto-Lei Couto Ferraz, de 1854. A ideia de incúria do povo é o suposto que aparece quando da nova ênfase dada à obrigatoriedade escolar, justo quando também predomina a ideia de ensino livre. Busca-se caracterizar uma certa "visão de mundo", no velho conceito de Dilthey, que será herdada pela República. O trabalho funda-se interpretativamente no resgate da tradição e na emergência do novo a partir dos impasses da tradição diante das questões do novo tempo, recorrendo a um procedimento hermenêutico sobre os discursos dos ministros do Império, bem como sobre os textos dos projetos e decretos. Recorre-se exaustivamente à obra de Primitivo Moacyr na trans- 
crição dos discursos dos ministros, a quem se vinculam as questões educacionais.

Palavras-chave: tradição; visão de mundo; herança.

Elementary education in the Leôncio de Carvalho Decree: a "world vision" inherited from Republican times?

This article points to the predominance of an idea which arose at the end of the Brazilian Empire, that of the curia of the people, and which, in the Republic that followed, was transformed into the civic insufficiency of the same people. The idea of the curia of the people did not last the duration of the Empire. It arose in the last 15 years of that period and changed the old imperial matrix of blaming the failure of policies on the failure of institutions. In order to demonstrate the predominance of this new idea in the final phase of the Empire which changed the villain of history we took education policy in the way in which it was expressed by the Minister Liberato Barroso and in projects of law which were debated in the General Assembly of the Empire (Paulino de Souza and João Alfredo) as well as in the Decree-Law Leôncio de Carvalho, always in counterpoint with the tradition passed on from the Decree-Law Couto Ferraz of 1854. The idea of the curia of the people is the supposition which appears when new emphasis is given to obligatory schooling, exactly when the idea of free education also predominated. An attempt is made to characterize a certain "world vision", in the old concept of Dilthey which will be inherited by the Republic. The work is based analytically on rescuing the tradition and on the emergence of the new based on the impasses of the tradition when faced with questions of the new era. It applies a hermeneutical procedure to the discourses of the ministers of the Empire, as well as to the texts of projects and decrees. Exhaustive use was made of the work of Primitivo Moacyr for the transcription of the minister's discourses to which the educational questions are linked. Key words: tradition; world vision; inheritance.

\section{La enseñanza elementar en el} decreto Leôncio de Carvalho: ¿"visión de mundo" heredada por el tiempo republicano?

Este artículo menciona el predominio de una idea que surgió al final del Imperio en Brasil, la de negligencia del pueblo, y que, en la república que vino a seguir, se transformó en insuficiencia cívica, de este mismo pueblo. La idea de negligencia del pueblo no postergó el Imperio; ella surgió en sus últimos quince años del mismo, mudando la vieja matriz imperial de culpar el fracaso de las políticas a las fallas de las instituciones. Para demostrar el predominio de esa nueva idea en esa fase final del Imperio, que mudó el villano de la historia, se toma la politica de educación en la forma como se expresó el ministro Liberato Barroso y en los proyectos de ley que son discutidos en la Asamblea General del Imperio (Paulino de Souza y João Alfredo), bien como en el Decreto Ley Leôncio de Carvalho, siempre en contrapunto con la tradición resultado del Decreto Ley Couto Ferraz, de 1854. La idea de negligencia del pueblo es lo supuesto que aparece cuando de la nueva énfasis dada a la obligatoriedad escolar, justo cuando también predomina la idea de enseñanza libre. Se busca caracterizar una cierta "visión de mundo", en el viejo concepto de Dilthey, que será heredada por la República. El trabajo se funda en el rescate de la tradición y en la emergencia de lo nuevo a partir de los obstáculos de la tradición a las cuestiones del nuevo tiempo, recurriendo a un procedimiento hermenéutico sobre los discursos de los ministros del
Imperio, bien como sobre los textos de los proyectos y decretos. Se recurre exhaustivamente a la obra de Primitivo Moacyr en la transcripción de los discursos de los ministros a quienes se vinculan las cuestiones educacionales.

Palabras claves: tradición; visión de mundo; herencia. 